\title{
The Development of Small Business and Private Entrepreneurship
}

\author{
Sherzod Yunusovich Salimov*
}

Scientific Researcher Scientific and Enlightenment Complex, The Republic of Uzbekistan Islam Karimov, Tashkent, Uzbekistan

\begin{abstract}
This article focuses on issues like how development of small-sized business and private entrepreneurship make their deal to not only improvement of a national economy but also increasing quality of lifestyle in our country, making a special climate better and especially decreasing number of the unemployed.
\end{abstract}

Keywords: Population; Small-sized business and private entrepreneurship; Social; Foreign; Investment

\section{Short Communication}

These days a great attention is being given for developing smallsized business in our republic and improving private entrepreneurship since these aspects are perceived a strategic mission of our governments' economic policy. Small-sized business as an activeness not requiring much capital ensures high degree of circulation of resources in the state of capital insufficiency. This sector exponentially and economically solves problems relating to restructuring economy, shaping consumer market in the state of economic instability and filling this market. Small companies adjust to change of consumers' demand fast; thereby, they provide required balance in consumer market. Now, this aspect is playing a crucial role in not only getting growing rate of economy to accelerate but increasing employment rate and population's income, issues very important for our government, as well. The fact that the number of companies involved in small-sized business and private entrepreneurship is growing shows how the sector is progressing efficiently. Small-sized business and private entrepreneurship is consolidating its position in population's life. Notwithstanding a small scale, this sector does hold an important role in ensuring a stable development of economy, providing population with employment and creating prosperity in people's life. As a result of taken steps share of small-sized business, private entrepreneurship and manufacturing products of industry in GDP has changed from $31 \%$ to $56.9 \%$ and from $12.9 \%$ to $45 \%$ respectively starting from 2000 . Nowadays, $78 \%$ of our current workforce is employed in this sector [1].

Further, $3^{\text {rd }}$ direction of this strategy of actions is devoted to "Prime ways of developing economy and liberating it", in fourth part (Decreasing involvement of government in economy, protecting the right of private ownership and reinforcing its position, continuing institutional and constitutive reforms addressed to encouraging smallsized business and private entrepreneurship) following issues are underlined:

- Ensuring a confident protection of private property and its rights, giving a wide freedom to development of private entrepreneurship and small-sized business, putting into action a principle that "If population becomes rich, then government also gets rich and strong".

- Creating a climate of entrepreneurship for widely enhancing small-sized business and private entrepreneurship, completely preventing illegal intrusion of government and other authorities to activeness of enterprises.

- Turning state property into private and simplifying rules involved, decreasing participation of government in shaping balance of enterprises, creating all facilities for developing entrepreneurship in properties turned into private.

- Improving investment climate, attracting foreign, especially direct foreign, investment to sectors of country's economy and areas.

- Implementing modern standards and styles of corporate management, strengthening role of stockholders in strategic management of companies.

- Developing and simplifying rules and mechanism for connecting entrepreneurs to engineering systems.

- Decreasing participation of government in controlling process of socio-economic development, getting systems of government management out of focused control and driving it to democracy, promoting government-private companionship, reinforcing role of social and self-controlling organizations.

In general, enhancing public openness and competitiveness, ensuring free economic activeness, developing macro-economic stability and keeping growing rate economic growth, activating privileged sectors of economy and modernizing reviewing reforms in the sphere of bank and finance, widening external economic connections, implementing foreign investments, improving tourism effectively, putting into action constitutive change. Furthermore, ensuring stability of national currency and prices to fulfill measures to be taken in this sector, working out modern market mechanisms for controlling currency rate step-by-step, widening revenue base of local budget, expanding external economic connections, implementing modern technologies for producing goods and materials meant for export, improving transport-logistic infrastructure and entrepreneurship, making investment for foreign investors more appealing, developing administration, implementing modern principles and mechanisms for controlling bank activeness, shaping agricultural unions with multiple sectors are mentioned.

During 2017 and 2021 program including 649 investment projects with value of 40 billion US dollars are planned to put into action. As a

*Corresponding author: Sherzod Yunusovich Salimov, Scientific Researcher Scientific and Enlightenment Complex, The Republic of Uzbekistan Islam Karimov, Tashkent, Uzbekistan, Tel: 9985647891; E-mail: zippt@mail.ru

Received June 08, 2018; Accepted June 29, 2018; Published August 07, 2018

Citation: Salimov SY (2018) The Development of Small Business and Private Entrepreneurship. Int J Econ Manag Sci 7: 535. doi: 10.4172/2162-6359.1000535

Copyright: ( 2018 Salimov SY. This is an open-access article distributed under the terms of the Creative Commons Attribution License, which permits unrestricted use, distribution, and reproduction in any medium, provided the original author and source are credited. 
consequence, during following 5 years production will increase by 1.5 times, its share in GDP change from $33.6 \%$ to $36 \%$ and reproduction's share will shift from $80 \%$ to $85 \%$ [2].

Throughout last 10 years, with the purpose of simplifying running a business mechanism for allocating credits for small-sized business and private entrepreneurship was simplified. More developing this mechanism, a number of incentives were given to enterprises. All of this will definitely give a chance to fortify role of small-sized business and private entrepreneurship in economy and to expand its share. Government's GDP changed from $31 \%$ in 2000 to $56.7 \%$, or rose by 1.8 times. In this sector share of total products of industry is $43.8 \%$, export is $31.8 \%$, investment is $38.3 \%$, and $77.8 \%$ of workforce is employed in this sector. These facts confirm all ongoing reforms.

It should be mentioned that, together with the fact that a lot of privileges and facilities are being created for entrepreneurs, there are some problems associated with expanding their activeness and growing potential of export:

- Complexity of mechanism for conducting export of small-sized business companys' goods and services, high cost of length of time to be spent.

- Poor installment of special system's activeness that organizes expanding of participation of small-sized business and private entrepreneurship proprietors.

- High rate of demand for consulting companies and systems that help to arrange process of production and selling of products manufactured for export by entrepreneurs. Inferring from aforementioned facts, it should be stated that issues of developing Uzbekistan's external trade connections and improving role of entrepreneurs of small-sized business and private entrepreneurship are remaining topical from the principle of future actions. Therefore, we think that taking following measures for developing small-sized business and private entrepreneurship's export potential.
- Arranging specialized wholesale markets, fairs in order to sell products manufactured by small-sized business, private entrepreneurship and government organizations representatives, helping by giving for rental or by selling buildings, constructions, machines, production and additional buildings, properties of government so as to organize their activeness.

- In privileged sectors of economy, especially in agriculture, manufacturing agricultural products and reprocessing them, producing consumer products, products of industry, food, drugs and pills, medical instruments, providing municipal and other services, erecting objects with production and social purposes, increasing rate of giving incentives and privileges to small-sized business and private entrepreneurship in the sector of arranging innovative activeness and sector requiring science.

In conclusion, adopted with the initiative of the president of the Republic of Uzbekistan Sh.Mirziyoev and going with an intensive progress decree, analysis of strategy of actions for further developing the republic of Uzbekistan gave a chance to create a lot of new work positions in improving national economy, to assist in expanding real income of population to further enhancing small-sized business and private entrepreneurship and to infer about emerging new opportunities. We believe, these processes allow us not only to keep growing rate of country's GDP but also to intensify this growth exponentially, and in near future Uzbekistan will become a country to be shown as an example, a country among leading ones with indicators of economic growth.

\section{References}

1. Monetary policy is the right thing to do (2018), Bank of the republic of Uzbekistan bank reports.

2. On Strategies for Further Development of the Republic of Uzbekistan O ' the Decree of the President of the Republic of Uzbekistan (2018), p: 28. 